\title{
The Impact of Financial Development on Corporate Performance: Theory and Evidence
}

\author{
Thu-Trang Thi Doan ${ }^{1} \&$ Toan Ngoc Bui ${ }^{1}$ \\ ${ }^{1}$ Faculty of Finance and Banking, Industrial University of Ho Chi Minh City (IUH), Vietnam \\ Correspondence: Toan Ngoc Bui, Faculty of Finance and Banking, Industrial University of Ho Chi Minh City (IUH), \\ Vietnam.
}

Received: July 20, 2020

doi:10.5430/ijfr.v12n1p214
Accepted: October 12, 2020

Online Published: December 24, 2020

URL: https://doi.org/10.5430/ijfr.v12n1p214

\begin{abstract}
This paper investigates the impact of financial development on corporate performance. Particularly, financial development is approximated by the parallel development of the banking system and stock market, which is expected to demonstrate the multidimensional nature in financial development. Specially, we consider the influence of financial development on corporate performance by exploring the theoretical and empirical works, a novel way of approaching the problem. We analyse the data of logistics sector and financial development in Vietnam, an economy whose logistics sector is relatively limited and financial development is quite fledging, but has enormous potential. Therefore, this study is expected to identify a number of unprecedented findings. The Generalized Method of Moment (GMM) is chosen for the analysis to ensure the reliable results. We successfully find that the banking system plays an essential role in enhancing corporate performance while the stock market does not perform this role. Admittedly, this is an interesting finding which brings the novelty of this study.
\end{abstract}

Keywords: corporate performance, domestic credit, financial development, stock market, Vietnam

\section{Introduction}

Financial development can be defined as improvements in the financial sector, mainly focused on development in the banking system and the stock market (Greenwood \& Jovanovic, 1990; Bencivenga \& Smith, 1991; Pradhan et al., 2014; Bui, 2020a; Nguyen et al., 2020). In other words, financial development enables the efficient resource allocation in the economy (Cherif \& Dreger, 2016; Bui, 2020b) as well as a better performance (Nguyen \& Bui, 2020), which greatly contributes in promoting corporate performance. The logistics sector is a young industry with enormous potential for development in Vietnam. This is because Vietnam is a developing country with lots of considerable achievements in international economic integration, which in turn brings Vietnam a big number of potential domestic and foreign customers. To meet requirements of stronger development and competition, young logistics firms in small size are facing bigger challenges in accessing capital. Hence, financial development is essential to logistics enterprises, especially in enhancing corporate performance. Indeed, financial development allows the companies to facilitate raising their efficiency as well as profits (King \& Levine, 1993; Levine, 2005; Bui, 2020b). The improvements in financial development helps firms easily access to bank loans as well as capital by capital issue. The causal relationship between financial development and capital structure has been investigated by Guiso et al. (2004), Dehejia et al. (2007), Fafchamps and Schündeln (2013), Lee (2015), O'Toole and Newman (2017). However, these empirical studies have limitations when financial development is only examined by developments in the banking system, not by the parallel development of the banking system and stock market. Actually, these firms can raise capital from both banks and stock market. In the context of international economic integration, medium-term and long-term capital is vital to companies (Bui, 2019; 2020c). Thus, investigating financial development through the parallel development of the banking sector and stock market is really necessary, which also allows to overcome the limitations in the existing studies. By this study, we consider the impact of financial development on corporate performance theoretically and empirically, a new approach as compared to the previous ones. Furthermore, the data are obtained in Vietnam, a developing economy with the limited financial development and nascent logistics sector. We thus expect to reveal first empirical evidence in Vietnam.

\section{Literature Review}

Financial development can be understood as development in the overall size of financial sector and its individual 
participants' efficiency (Zaman et al., 2012; Bui, 2020d). To be specific, financial development is development of the banking system and stock market, an essential base to determine how to measure financial development (Greenwood \& Jovanovic, 1990; Bencivenga \& Smith, 1991; Pradhan et al., 2014; Bui, 2020a; Nguyen et al., 2020). In fact, financial development is frequently approximated by domestic credit to private sector (Fisman \& Love, 2003; Shen, 2013; Choi \& Park, 2017; Lim, 2018; Bui, 2020a, 2020b) and stock market capitalization (Fisman \& Love, 2003; Shen, 2013; Choi \& Park, 2017), which are two major indicators of size of the banking system and stock market relative to the economy, which means financial development of each economy (Greenwood \& Jovanovic, 1990; Bencivenga \& Smith, 1991; Pradhan et al., 2014; Bui, 2020d).

In countries with a limited financial development, the banking system plays a major role in supplying credit to the economy while the stock market has a smaller size relative to the economy (Nguyen \& Bui, 2019). Therefore, a majority of existing studies usually employ domestic credit to private sector (\% of GDP) as a proxy of financial development (Ashraf, 2017). This measure can suit the contexts in some certain countries but still has its own limitation when only considering financial development through the banking system's development. When international economic integration has accelerated among lots of countries, the stock market is also important for companies to raise their capital access. Hence, financial development should be measured by the parallel development of the banking sector and stock market in order to demonstrate the multidimensional nature of financial development correctly.

Financial development plays a crucial role in allowing firms to maintain their performance (King \& Levine, 1993), raising their capital access (Rajan \& Zingales, 1998; Levine et al., 2000; Love, 2003; Beck et al., 2006), and more notably, improving their profitability (King \& Levine, 1993; Levine, 2005). Consequently, there have been a large number of empirical scholars analysing the significant impact of financial development on corporate performance, namely Guiso et al. (2004), Fafchamps and Schündeln (2013), Lee (2015). Together with considering the direct impact of financial development on corporate performance, Dehejia et al. (2007) emphasized that financial expansion enables to foster growth in manufacturing industry. In another analysis, Chauvet and Jacolin (2017) confirmed that the growth process in private sector frequently has its difficulties in credit access. Besides, Fowowe (2017) declared that advantages in the credit access process will promote growth rate of African companies. More than that, O'Toole and Newman (2017) confirmed the major role of financial development in accelerating the corporate growth rate.

Generally, a large body of previous research suggests that financial development positively affects corporate performance. Nevertheless, there still exist limitations when financial development is only examined through development in the banking system, not the stock market. This is a big gap in the existing studies.

\section{Research Methodology}

Methodologically, we estimate the model by employing the Pooled Regression Model, Fixed Effects Model and Random Effects Model, which are the fundamental analyses appropriate for panel data (Doan, 2020a, 2020b). Their results, however, can be unreliable if the tests are violated. Hence, we adopt the Generalized Method of Moment (GMM) for the estimation to ensure the most reliable results. Thanks to this analysis, the results will overcome the violated hypotheses phạm (Doytch \& Uctum, 2011) as well as control potential endogeneity (Doan \& Bui, 2020).

In this paper, we obtain the database from financial statements of 28 logistics firms and statistical indicators released by World Bank in the 2015-2019 periods. Specifically, we use the financial reports to collect firm-specific data while the World Bank's database is adopted for data on financial development and economic growth.

We choose the ratio of net income to total assets as a proxy of corporate performance (Y). Financial development is approximated by two independent variables which are domestic credit to private sector (X1) and stock market capitalization (X2). In addition, the control variables as indicators of firm characteristics (financial leverage (X3) and firm size (X4)) and the macroeconomy (economic growth (X5)) are included, following what have been suggested by Lee (2015), Vithessonthi and Tongurai (2015). It can be admitted that little attention has been given to analyse both indicators of firm characteristics and macroeconomic factors. The study is thus expected to reveal more reliable results than the previous ones.

Consequently, the suggested model is estimated as follows:

$$
\mathrm{Y}=\mathrm{f}(\mathrm{X} 1, \mathrm{X} 2, \mathrm{X} 3, \mathrm{X} 4, \mathrm{X} 5)
$$

Where: Dependent variable includes corporate performance $(\mathrm{Y})$, measured by the ratio of net income to total assets. Independent variables consist of domestic credit to private sector (\% of GDP) (X1) and stock market capitalization (\% of GDP) (X2). Control variables are financial leverage (X3 = total debt / total assets), firm size (X4 = logarithm of total assets), and economic growth (X5 = GDP growth). 


\section{Data Analysis and Discussion}

The estimation results by adopting the Pooled Regression Model, Fixed Effects Model, and Random Effects Model are presented in Table 1 as follows:

Table 1. Regression models

\begin{tabular}{llll}
\hline $\mathrm{Y}$ & Pooled Regression Model & Fixed Effects Model & Random Effects Model \\
\hline Constant & $-40.930^{* * * *}$ & $-60.484^{* * *}$ & $-48.555^{* * * *}$ \\
\hline $\mathrm{X} 1$ & $0.465^{* * *}$ & $0.454^{* * * *}$ & $0.461^{* * *}$ \\
\hline $\mathrm{X} 2$ & -0.066 & -0.067 & -0.065 \\
\hline $\mathrm{X} 3$ & $-0.061^{* * * *}$ & -0.063 & $-0.063^{* *}$ \\
\hline $\mathrm{X} 4$ & 0.452 & $1.262^{* * *}$ & $0.769^{*}$ \\
\hline $\mathrm{X} 5$ & -1.738 & -1.816 & -1.767 \\
\hline R-squared & $31.94 \%$ & $45.67 \%$ & $45.37 \%$ \\
\hline Significance level & $\mathrm{F}(5,134)=12.58$ & $\mathrm{~F}(5,107)=17.99$ & Wald chi2 $(5)=92.85$ \\
\hline F test & Prob>F $=0.000^{* * * *}$ & Prob $>\mathrm{F}=0.000^{* * *}$ & Prob>chi2 $=0.000^{* * *}$ \\
\hline Hausman test & $\mathrm{F}(27,107)=4.00$ & & \\
\hline & Prob $>\mathrm{F}=0.000^{* * * *}$ & & \\
\hline
\end{tabular}

Note: ${ }^{* * *}$ and ${ }^{* * *}$ indicate significance at the $10 \%, 5 \%$ and $1 \%$ level, respectively.

Table 1 show that the Random Effects Model is more appropriate. In specific, the $F$ test $(F(27,107)=4.00)$ is significant at the $1 \%$ level and the Hausman test $(\operatorname{chi} 2(5)=1.26)$ has no significance. Accordingly, the Random Effects Model is chosen for the next steps.

Table 2. Testing research model

\begin{tabular}{|c|c|c|c|}
\hline \multicolumn{2}{|c|}{ Multicollinearity test } & \multirow{2}{*}{ Heteroscedasticity test } & \multirow{2}{*}{ Autocorrelation test } \\
\hline Variable & VIF & & \\
\hline $\mathrm{X} 1$ & 3.63 & \multirow{6}{*}{$\begin{array}{l}\text { chibar } 2(01)=37.97 \\
\text { Prob }>\text { chibar } 2=0.000^{* * *}\end{array}$} & \multirow{6}{*}{$\begin{array}{l}F(1,27)=1.057 \\
\text { Prob }>F=0.313\end{array}$} \\
\hline $\mathrm{X} 2$ & 1.02 & & \\
\hline $\mathrm{X} 3$ & 1.02 & & \\
\hline $\mathrm{X} 4$ & 1.02 & & \\
\hline $\mathrm{X} 5$ & 3.63 & & \\
\hline Mean VIF & & & \\
\hline
\end{tabular}

Table 2 indicates that there is no serious issue of multicollinearity with a relatively small VIF. Also, autocorrelation does not really exist. Heteroscedasticity, however, is significant at the $1 \%$ level. Thus, the GMM is adopted for the estimation to guarantee the most reliable results. 
Table 3. GMM estimation results

\begin{tabular}{lll}
\hline $\mathrm{Y}$ & Coef. & $\mathrm{P}>|\mathrm{z}|$ \\
\hline Constant & $-47.088^{* * *}$ & 0.001 \\
\hline $\mathrm{X} 1$ & $0.424^{* * *}$ & 0.000 \\
\hline $\mathrm{X} 2$ & $-0.087^{* *}$ & 0.037 \\
\hline $\mathrm{X} 3$ & $-0.092^{* * *}$ & 0.002 \\
\hline $\mathrm{X} 4$ & $0.778^{*}$ & 0.093 \\
\hline $\mathrm{X} 5$ & -1.033 & 0.164 \\
\hline Significance level & Wald chi2(4) $=96.15$ & \\
& Prob $>$ chi2 $=0.000^{* * *}$ & \\
\hline Arellano-Bond test & $\mathrm{z}=-1.29$ & \\
& Pr $>\mathrm{z}=0.195$ & \\
\hline Sargan test & chi2 $(3)=5.24$ & \\
& Prob $>$ chi2 $=0.155$ & \\
\hline
\end{tabular}

Note: ${ }^{*},{ }^{* *}$ and ${ }^{* * *}$ indicate significance at the $10 \%, 5 \%$ and $1 \%$ level, respectively.

As can be seen from Table 3, the estimation results employing the GMM have significance at the $1 \%$ level. Meanwhile, the results of Sargan and Arellano-Bond tests are appropriate. Thus, the results are valid for the analysis. Alternatively, financial development significantly runs corporate performance. To be specific, corporate performance $(\mathrm{Y})$ is positively $(\beta=0.424)$ affected by domestic credit to private sector $(\mathrm{X} 1)$ at the $1 \%$ level of significance. Also, stock market capitalization (X2) is negatively $(\beta=-0.087)$ correlated to corporate performance at the $5 \%$ level of significance. This is consistent with what is happening among Vietnamese logistics companies. Indeed, the banking system plays a key role in supplying credit to these companies. A strongly developed banking system facilitates these firms to access credit in order that they can expand their investment and promote their profit. This result is in line with what have been suggested by Guiso et al. (2004), Fafchamps and Schündeln (2013), Lee (2015), O'Toole and Newman (2017). Interestingly, the causality between financial development and corporate performance is totally different from the perspective of the stock market. In specific, stock market capitalization (X2) exerts a negative effect on corporate performance (Y), but at a low level. This indicates that development in the stock market does not certainly lead to positive impact on the profitability in logistics firms. It is straightforward because firms with high market capitalization tend to make less trading. On the other hand, both size and number of logistics firms listed on the stock market are still limited. Therefore, Vietnam's stock market cannot perform their function well in by supplying medium-term and long-term capital to promote corporate performance in the logistics sector.

Beside the considerable effect of financial development on corporate performance, the results also reveal that corporate performance is affected negatively by financial leverage (X3) and positively by firm size (X4). It can be concluded that firm-specific factors are really essential to corporate performance. Specifically, small firms with less debt will be more advantageous to enhance corporate performance. It is straightforward because fledging firms have shorter time in using debt, which cannot improve the profitability.

\section{Conclusion}

By confirming the significant impact of financial development on corporate performance in Vietnamese logistics companies, we obtain the objective of this study. Furthermore, we succeed in finding the major role of the banking sector in promoting corporate performance. Meanwhile, the stock market cannot perform this function. These are admittedly unprecedented findings of this study. They are essential for policymakers in developing detailed solutions to foster financial development in the combination with corporate performance in the logistics sector. Despite achieving the objectives, the paper has its own limitations when only approximating corporate performance by the ratio of net income to total assets. Other proxies like the ratio of net income to equity, net income to revenue are suggested to be employed in future studies. 


\section{References}

Ashraf, B. N. (2017). Do Trade and financial openness: impact on bank development of emerging economies. Research in International Business and Finance, 44(C), 434-458. https://doi.org/10.1016/j.ribaf.2017.07.115

Beck, T., Demirguc-Kunt, A., Laeven, L., \& Maksimovic, V. (2006). The determinants of financing obstacles. Journal of InternationalMoney and Finance, 25(6), 932-952. https://doi.org/10.1016/j.jimonfin.2006.07.005

Bencivenga, V. R., \& Smith, B. D. (1991). Financial intermediation and endogenous growth. Review of Economic Studies, 58(2), 195-209. https://doi.org/10.2307/2297964

Bui, T. N. (2019). Inflation and stock index: Evidence from Vietnam. Journal of Management Information and Decision Science, 22(4), 408-414.

Bui, T. N. (2020a). Financial development in Vietnam: An overview. Journal of Asian Finance, Economics and Business, 7(9), 169-178. https://doi.org/10.13106/JAFEB.2020.VOL7.NO9.169

Bui, T. N. (2020b). How does financial development affect the employment? Evidence from asean countries. Journal of Management Information and Decision Science, 23(1), 1-5.

Bui, T. N. (2020c). Stock holding decisions of foreign investors in emerging stock markets: A case study in Vietnam. Management Science Letters, 10(3), 625-630. https://doi.org/10.5267/j.msl.2019.9.017

Bui, T. N. (2020d). Financial depth and the real estate market: An empirical study of the wealth effect. Asian Economic and Financial Review, 10(8), 936-945. https://doi.org/10.18488/journal.aefr.2020.108.936.945

Chauvet, L., \& Jacolin, L. (2017). Financial inclusion, bank concentration, and firm performance. World Development, 97, 1-13. https://doi.org/10.1016/j.worlddev.2017.03.018

Cherif, M., \& Dreger, C. (2016). Institutional determinants of financial development in MENA countries. Review of Development Economics, 20(3), 670-680. https://doi.org/10.1111/rode.12192

Choi, C., \& Park, K. (2017). Financial system and housing price. Emerging Markets Finance and Trade, 54(2), 328-335. https://doi.org/10.1080/1540496X.2017.1344832

Dehejia, R. H., \& Lleras-Muney, A. (2007). Financial development and pathways of growth: state branching and deposit insurance laws in the United States, 1900-1940. Journal of Law and Economics, 50(2), $239-272$. https://doi.org/10.1086/511322

Doan, T. T. T. (2020a). Determinants of financing decisions: Evidence using GMM estimation. Accounting, 6(5), 681-686. https://doi.org/10.5267/j.ac.2020.6.016

Doan, T. T. T. (2020b). The effect of cash holdings on firm performance: Evidence from Vietnam listed firms. Accounting, 6(5), 721-726. https://doi.org/10.5267/j.ac.2020.6.012

Doan, T. T. T., \& Bui, T. N. (2020). Nonlinear impact of supply chain finance on the performance of seafood firms: A case study from Vietnam. Uncertain Supply Chain Management, 8(2), $267-272$. https://doi.org/10.5267/j.uscm.2020.1.001

Doytch, N., \& Uctum, M. (2011). Does the worldwide shift of FDI from manufacturing to services accelerate economic growth? A GMM estimation study. Journal of International Money and Finance, 30(3), $410-427$. https://doi.org/10.1016/j.jimonfin.2011.01.001

Fafchamps, M., \& Schündeln, M. (2013). Local financial development and firm performance: Evidence from Morocco. Journal of Development Economics, 103, 15-28. https://doi.org/10.1016/j.jdeveco.2013.01.010

Fisman, R., \& Love, I. (2003). Trade credit, financial intermediary development, and industry growth. The Journal of Finance, 58(1), 353-374. https://doi.org/10.1111/1540-6261.00527

Fowowe, B. (2017). Access to finance and firm performance: Evidence from African countries. Review of Development Finance, 7(1), 6-17. https://doi.org/10.1016/j.rdf.2017.01.006

Greenwood, J., \& Jovanovic, B. (1990). Financial development, growth, and the distribution of income. Journal of Political Economy, 98(5), 1076-1107. https://doi.org/10.1086/261720

Guiso, L., Sapienza, P., \& Zingales, L. (2004). Does local financial development matter?. Quarterly Journal of Economics, 119(3), 929-969. https://doi.org/10.1162/0033553041502162

King, R. G., \& Levine, R. (1993). Finance and growth: Schumpeter might be right. Quarterly Journal of Economics, 108(3), 717-737. https://doi.org/10.2307/2118406 
Lee, M. (2015). How did financial development affect the performance of european firms before and after the 2008 credit crisis?. Eastern European Economics, 53(6), 514-528. https://doi.org/10.1080/00128775.2015.1078217

Levine, R. (2005). Finance and growth: theory and evidence. Handbook of Economic Growth, 1, 865-934. https://doi.org/10.3386/w10766

Levine, R., Loayza, N., \& Beck, T. (2000). Financial intermediation and growth: Causality and causes. Journal of Monetary Economics, 46(1), 31-77. https://doi.org/10.1016/S0304-3932(00)00017-9

Lim, T. (2018). Growth, financial development, and housing booms. Economic Modelling, 69, 91-102. https://doi.org/10.1016/j.econmod.2017.09.008

Love, I. (2003). Financial development and financing constraints: International evidence from the structural investment model. Review of Financial Studies, 16(3), 765-791. https://doi.org/10.1093/rfs/hhg013

Nguyen, M. L. T., \& Bui, T. N. (2019). Stock market, real estate market, and economic growth: an ARDL approach. Investment Management and Financial Innovations, 16(4), 290-302. https://doi.org/10.21511/imfi.16(4).2019.25

Nguyen, M. L. T., \& Bui, T. N. (2020). The real estate market and financial stability. International Journal of

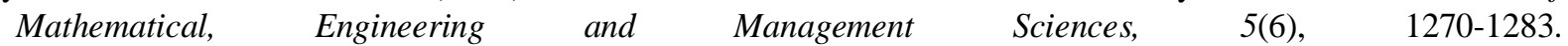
https://doi.org/10.33889/IJMEMS.2020.5.6.094

Nguyen, M. L. T., Xuan, P. T. T., \& Bui, T. N. (2020). Causal relationship between banking system development and real estate market. Management Science Letters, 10(1), 41-52. https://doi.org/10.5267/j.msl.2019.8.017

O'Toole, C., \& Newman, C. (2017). Investment financing and financial development: evidence from Viet Nam. Review of Finance, 21(4), 1639-1674. https://doi.org/10.1093/rof/rfw017

Pradhan, R., Arvin, M., Hall, J., \& Bahmani, S. (2014). Causal nexus between economic growth, banking sector development, stock market development, and other macroeconomic variables: The case of ASEAN countries. Review of Financial Economics, 23(4), 155-173. https://doi.org/10.1016/j.rfe.2014.07.002

Rajan, R. G., \& Zingales, L. (1998). Financial dependence and growth. American Economic Review, 88(3), 559-586.

Shen, L. (2013). Financial dependence and growth: diminishing returns to improvement in financial development. Economics Letters, 120(2), 215-219. https://doi.org/10.1016/j.econlet.2013.04.018

Vithessonthi, C., \& Tongurai, J. (2015). The effect of leverage on performance: Domestically-oriented versus internationally-oriented firms. Research in International Business and Finance, 34, 265-280.

Zaman, K., Izhar, Z., Khan, M. M., \& Ahmad, M. (2012). The relationship between financial indicators and human

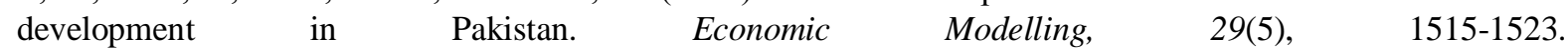
https://doi.org/10.1016/j.econmod.2012.05.013

\section{Copyrights}

Copyright for this article is retained by the author(s), with first publication rights granted to the journal.

This is an open-access article distributed under the terms and conditions of the Creative Commons Attribution license (http://creativecommons.org/licenses/by/4.0/). 